War of Shadows 


$$
\text { @ }
$$




\section{War of Shadows}

THE STRUGGLE FOR UTOPIA IN

THE PERUVIAN AMAZON

MICHAEL F. BROW N

AND EDUARDO FERNÁNDEZ

UNIVERSITY OF CALIFORNIA PRESS

BERKELEY LOS ANGELES OXFORD

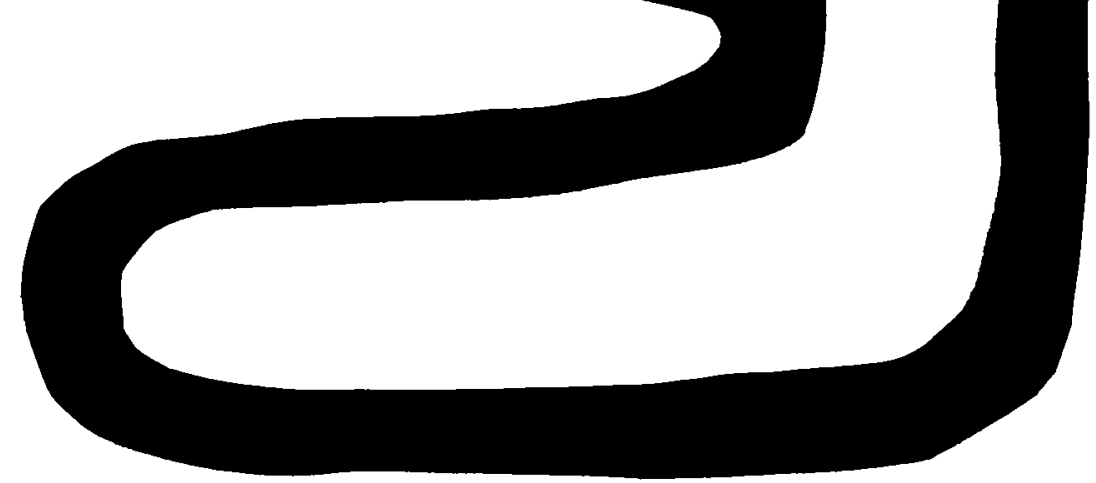


University of California Press

Berkeley and Los Angeles, California

University of California Press

Oxford, England

Copyright (C) I99 I by The Regents of the University of California

Library of Congress Cataloging-in-Publication Data

Brown, Michael Fobes, 1950-

War of shadows : the struggle for utopia in the Peruvian

Amazon / Michael F. Brown and Eduardo Fernández.

p. $\mathrm{cm}$.

Includes bibliographical references and index.

ISBN 0-520-07435-1 (cloth : alk. paper)

1. Campa Indians-Wars. 2. Campa Indians-Government relations. 3. Campa Indians-Social conditions. 4. Nativistic movements-Peru-Satipo. 5. Indians, Treatment of-PeruSatipo. 6. Satipo (Peru)-Social conditions. 7. Movimiento de Izquierda Revolucionaria (Peru) I. Fernández, Eduardo. II. Title.

F3430.1.C3B76 1991

$985^{\prime} .24-\mathrm{dc} 20$

Printed in the United States of America

$\begin{array}{lllllllll}\text { I } & 2 & 3 & 4 & 5 & 6 & 7 & 8 & 9\end{array}$

The paper used in this publication meets the minimum requirements of American National Standard for Information Sciences-Permanence of Paper for Printed Library Materials, ANSI Z39.48-I984@ 


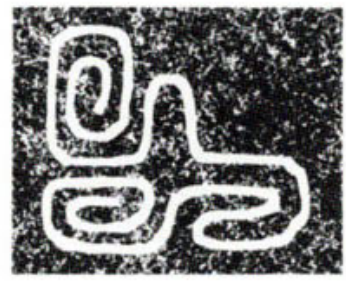

When I wish to evoke the image of the Antis Indians, they very often appear to me in this way: as the Spirits of the Jungle, crepuscular beings, vague forms, Chinese shadows dancing in the moonlight.

Olivier Ordinaire, Du Pacifique à

l'Atlantique par les Andes péruviennes et l'Amazone, 1892 
